\title{
Epididymal Neoplasm
}

National Cancer Institute

\section{Source}

National Cancer Institute. Epididymal Neoplasm. NCI Thesaurus. Code C39958.

A benign or malignant neoplasm that affects the epididymis. Representative examples

include epididymal adenomatoid tumor and epididymal adenocarcinoma. 